\title{
Synthesis, spectral characterization of Schiff base transition metal complexes: DNA cleavage and antimicrobial activity studies
}

\author{
N RAMAN,* J DHAVEETHU RAJA and A SAKTHIVEL \\ Department of Chemistry, VHNSN College, Virudhunagar 626001 \\ e-mail: drn_raman@yahoo.co.in
}

MS received 1 May 2007; revised 7 July 2007

\begin{abstract}
A new series of transition metal complexes of $\mathrm{Cu}(\mathrm{II}), \mathrm{Ni}(\mathrm{II}), \mathrm{Co}(\mathrm{II}), \mathrm{Mn}(\mathrm{II}), \mathrm{Zn}(\mathrm{II}), \mathrm{VO}(\mathrm{IV})$, $\mathrm{Hg}(\mathrm{II})$ and $\mathrm{Cd}(\mathrm{II})$ have been synthesized from the Schiff base (L) derived from 4-aminoantipyrine, 3-hydroxy-4-nitrobenzaldehyde and $o$-phenylenediamine. Structural features were obtained from their elemental analyses, magnetic susceptibility, molar conductance, mass, IR, UV-Vis, ${ }^{1} \mathrm{H}$ NMR and ESR spectral studies. The data show that these complexes have composition of ML type. The UV-Vis, magnetic susceptibility and ESR spectral data of the complexes suggest a square-planar geometry around the central metal ion except VO(IV) complex which has square-pyramidal geometry. The redox behaviour of copper and vanadyl complexes was studied by cyclic voltammetry. Antimicrobial screening tests gave good results in the presence of metal ion in the ligand system. The nuclease activity of the above metal complexes shows that $\mathrm{Cu}, \mathrm{Ni}$ and $\mathrm{Co}$ complexes cleave DNA through redox chemistry whereas other complexes are not effective.
\end{abstract}

Keywords. Schiff base; 4-aminoantipyrine; CT DNA; nuclease activity; DNA cleavage; antimicrobial activity.

\section{Introduction}

Schiff base of 4-aminoantipyrine and its complexes have a variety of applications in biological, clinical, analytical and pharmacological areas. ${ }^{1-3}$ Studies of a new kind of chemotherapeutic Schiff bases are now attracting the attention of biochemists. ${ }^{4,5}$ Earlier work reported that some drugs showed increased activity, when administered as metal complexes rather than as organic compounds. ${ }^{6,7}$ Deoxyribonucleic acid (DNA) is the primary target molecule for most anticancer and antiviral therapies according to cell biologists. Investigations on the interaction of DNA with small molecules are important in the design of new types of pharmaceutical molecules. Since the chemical nuclease activity of transition metal complexes was discovered in the $1980 \mathrm{~s},{ }^{8,9}$ studying the interaction model and the mechanism of transition metal complexes with DNA, and exploring the application of metal complexes in antineoplastic medication, molecular biology and bioengineering have become hotspots in recent years. Some kind of metal complexes interacted with DNA could induce the

*For correspondence breakage of DNA strands by appropriate methods. In the case of cancer genes, after DNA strands are cleaved, the DNA double strands break. The replication ability of cancer gene is destroyed. Copper complex could cleave DNA in the presence of ascorbate or hydroquinone. ${ }^{11}$ It was suggested that the reductive capability of reductants had a critical influence on DNA cleavage. The coordinating property of 4-aminoantipyrine ligand has been modified to give a flexible ligand system, formed by condensation with a variety of reagents like aldehydes, ketones thiosemicarbazides and carbazides, etc. ${ }^{12-22}$ Literature search reveals that no work has been done on the condensation process of 4-aminoantipyrine, 3-hydroxy-4-nitrobenzaldehyde and $o$-phenylenediamine. In this paper we report the synthesis, characterization, redox, antimicrobial and DNA cleavage studies of transition metal complexes containing Schiff base derived from 4-aminoantipyrine, 3-hydroxy-4-nitrobenzaldehyde and $o$-phenylenediamine.

\section{Experimental}

Reagents such as 4-aminoantipyrine-3-hydroxy-4nitrobenzaldehyde, $o$-phenylenediamine, various 
metal(II) chlorides were of Merck products, CT DNA from GENEI were used as supplied. For voltammetric experiments, tetrabutylammonium perchlorate (TBAP) (Sigma) was used as supporting electrolyte. Anhydrous grade ethanol, DMF and DMSO were purified according to standard procedures. Microanalytical data of the compounds were recorded at Central Drug Research Institute (CDRI), Lucknow. The Mass spectra of the ligand and its complexes were recorded at the Indian Institute of Technology, Mumbai. ${ }^{1} \mathrm{H}-\mathrm{NMR}$ spectra $(300 \mathrm{MHz})$ of the samples were recorded in $\mathrm{CDCl}_{3}$ and DMSO$d_{6}$ by employing TMS as internal standard at the Madurai Kamaraj University, Madurai. IR spectra of the samples were recorded on a Perkin-Elmer 783 spectrophotometer in $4000-400 \mathrm{~cm}^{-1}$ range using $\mathrm{KBr}$ pellet. The UV-Vis spectra were recorded on a Shimadzu UV-1601 spectrophotometer using DMF as a solvent. The X-band ESR spectra of the complexes were recorded at 300 and $77 \mathrm{~K}$ at IIT, Mumbai using TCNE (tetracyanoethylene) as the g-marker. Magnetic susceptibility of the complexes was measured by Guoy balance using copper sulphate as calibrant. Electrochemical studies were carried out using EG\&G Princeton Applied Research Potentiostat/Galvanostat Model 273A, controlled by M270 software. Cyclic voltammogram was measured using a glassy carbon working electrode, platinum wire auxiliary electrode and an $\mathrm{Ag} / \mathrm{AgCl}$ reference electrode. All solutions were purged with $\mathrm{N}_{2}$ for $30 \mathrm{~min}$ before each experiment. The molar conductance of the complexes was measured using a Systronic conductivity bridge at room temperature in DMSO. Solutions of CT DNA (calf-thymus DNA) in $50 \mathrm{mM}$ $\mathrm{NaCl} / 50 \mathrm{mM}$ tris $-\mathrm{HCl}(\mathrm{pH}=7 \cdot 2)$ gave a ratio of $\mathrm{UV}$ absorbance at 260 and $280 \mathrm{~nm}, A_{260} / A_{280}$ of $\sim 1.8$ 1.9 , indicating that DNA was sufficiently free of protein contamination. ${ }^{23}$ DNA concentration was determined by UV absorbance at $260 \mathrm{~nm}$ after $1: 100$ dilutions. The molar absorption coefficient was taken as $6600 \mathrm{M}^{-1} \mathrm{~cm}^{-1}$. Stock solutions were kept at $4^{\circ} \mathrm{C}$ and used after not more than 4 days. Doubly distilled water was used to prepare the buffer. The antimicrobial activities of the ligands and their complexes were carried out by well-diffusion method.

\subsection{Syntheses of Schiff base (L)}

4-Aminoantipyrine $(2.033 \mathrm{~g}, 10 \mathrm{mM})$ in $40 \mathrm{~mL}$ of ethanol was stirred with 3-hydroxy-4-nitrobenzaldehyde $(1.671 \mathrm{~g}, 10 \mathrm{mM})$ for $\sim 1 \mathrm{~h}$. The yellow solid (I) formed was filtered and recrystallized from ethanol. Compound (I) $(7.04 \mathrm{~g}, 20 \mathrm{mM})$ in $50 \mathrm{~mL}$ of ethanol was refluxed with $o$-phenylenediamine $(1.08 \mathrm{~g}, 10 \mathrm{mM})$ for $\sim 36 \mathrm{~h}$ after adding anhydrous potassium carbonate. The potassium carbonate was filtered off from the reaction mixture and the solvent was evaporated. The red solid separated was filtered and recrystallized from ethanol (figure 1).

\subsection{Syntheses of complexes}

A solution of metal(II) chloride in ethanol $(2 \mathrm{mM})$ was refluxed with an ethanolic solution of the Schiff base $(2 \mathrm{mM})$ for $\sim 5 \mathrm{~h}$. The solution was then reduced to one-third on a water bath. The solid complex precipitated was filtered, washed thoroughly with ethanol and dried in vacuo. The oxovanadium(IV) complex was synthesized from the sulphate salt by the same procedure but in the presence of $5 \mathrm{~mL}$ of $5 \%$ aqueous sodium acetate solution.

\subsection{Antimicrobial activity}

The in vitro biological screening effects of the investigated compounds were tested against the bacteria: Salmonella typhi, Staphylococcus aureus, Escherichia coli, and Bacillus subtilis by the well-diffusion method, ${ }^{24}$ using agar nutrient as the medium. The antifungal activities of the compounds were evalu-

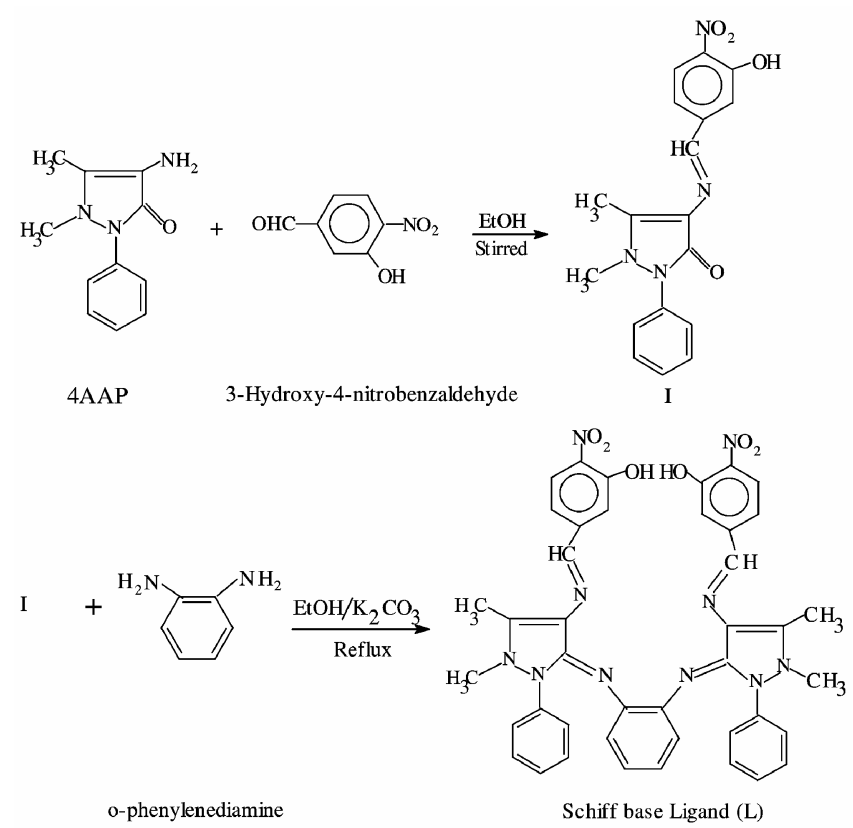

Figure 1. Formation of Schiff base ligand (L). 
ated by the well-diffusion method against the fungi viz., Aspergillus niger, Aspergillus flavus and Rhizoctonia bataicola cultured on potato dextrose agar as medium. The stock solution $\left(10^{-2} \mathrm{M}\right)$ was prepared by dissolving the compounds in DMSO and the solutions were serially diluted to find MIC values. In a typical procedure, ${ }^{25}$ a well was made on the agar medium inoculated with microorganisms. The well was filled with the test solution using a micropipette and the plate was incubated $24 \mathrm{~h}$ for bacteria and $72 \mathrm{~h}$ for fungi at $35^{\circ} \mathrm{C}$. During this period, the test solution diffused and the growth of the inoculated microorganisms was affected. The inhibition zone was developed, at which the concentration was noted.

\subsection{Gel electrophoresis}

The DNA cleavage experiment was conducted using CT DNA by gel electrophoresis with the corresponding metal complex in the presence of $\mathrm{H}_{2} \mathrm{O}_{2}$ as an oxidant. The reaction mixture was incubated before electrophoresis experiment at $35^{\circ} \mathrm{C}$ for $2 \mathrm{~h}$ as follows: CT DNA $30 \mu \mathrm{M}, 50 \mu \mathrm{M}$ each complex, $50 \mu \mathrm{M} \mathrm{H}_{2} \mathrm{O}_{2}$ in $50 \mathrm{mM}$ tris- $\mathrm{HCl}$ buffer $(\mathrm{pH}=7 \cdot 2)$. The samples were electrophoresed for $2 \mathrm{~h}$ at $50 \mathrm{~V}$ on
$1 \%$ agarose gel using tris-acetic acid-EDTA buffer, $\mathrm{pH}=8 \cdot 3$. After electrophoresis, the gel was stained using $1 \mu \mathrm{g} / \mathrm{cm}^{3}$ ethidiumbromide (EB) and photographed under UV light using Nikon camera.

\section{Results and discussion}

The analytical data for the ligand and complexes together with some physical properties are summarized in table 1. The data from complexes correspond well with the general formula $\mathrm{ML}$, where $\mathrm{M}=\mathrm{Cu}(\mathrm{II})$, $\mathrm{Ni}(\mathrm{II}), \mathrm{Co}(\mathrm{II}), \mathrm{Mn}(\mathrm{II}), \mathrm{Zn}(\mathrm{II}), \mathrm{Cd}(\mathrm{II}), \mathrm{Hg}(\mathrm{II})$ and $\mathrm{VO}(\mathrm{IV}) ; \mathrm{L}=\mathrm{C}_{42} \mathrm{H}_{36} \mathrm{~N}_{10} \mathrm{O}_{6}$. The magnetic susceptibilities of the complexes at room temperature were consistent with square-planar geometry around the central metal ion, except for the VO(IV) complex which shows a square-pyramidal geometry. The higher conductance values of chelates support their electrolytic nature of metal complexes.

\subsection{Mass spectra}

The ESI mass spectra of the ligand (L) and its copper complex $[\mathrm{CuL}] \mathrm{Cl}_{2}$ recorded at room temperature were used to compare their stoichiometry composition. The Schiff base showed a molecular ion peak at

Table 1. Physical characterization, analytical, molar conductance and magnetic susceptibility data of the ligand and the complexes.

\begin{tabular}{|c|c|c|c|c|c|c|c|c|c|}
\hline \multirow[b]{2}{*}{ Compound } & \multirow[b]{2}{*}{ Molecular formula } & \multirow[b]{2}{*}{ Colour } & \multirow{2}{*}{$\begin{array}{l}\text { Yield } \\
(\%)\end{array}$} & \multicolumn{4}{|c|}{ Found (Cacld) (\%) } & \multirow{2}{*}{$\begin{array}{c}\text { Molar } \\
\text { conductance } \\
\wedge_{\mathrm{m}}\left(\Omega^{-1}\right. \\
\left.\mathrm{cm}^{2} \mathrm{~mol}^{-1}\right)\end{array}$} & \multirow[b]{2}{*}{$\mu_{\text {eff }}(\mathrm{BM})$} \\
\hline & & & & M & $\mathrm{C}$ & $\mathrm{H}$ & $\mathrm{N}$ & & \\
\hline $\mathrm{L}$ & $\mathrm{C}_{42} \mathrm{H}_{36} \mathrm{~N}_{10} \mathrm{O}_{6}$ & Red & 74 & - & $\begin{array}{c}63 \cdot 8 \\
(64 \cdot 9)\end{array}$ & $\begin{array}{c}4 \cdot 4 \\
(4 \cdot 6)\end{array}$ & $\begin{array}{c}17 \cdot 8 \\
(18 \cdot 0)\end{array}$ & - & - \\
\hline$[\mathrm{CuL}] \mathrm{Cl}_{2}$ & $\mathrm{CuC}_{42} \mathrm{H}_{36} \mathrm{~N}_{10} \mathrm{O}_{6} \mathrm{Cl}_{2}$ & Dark brown & 56 & $\begin{array}{c}6 \cdot 8 \\
(6 \cdot 9)\end{array}$ & $\begin{array}{c}55 \cdot 1 \\
(55 \cdot 4)\end{array}$ & $\begin{array}{c}3 \cdot 8 \\
(4 \cdot 0)\end{array}$ & $\begin{array}{c}14.9 \\
(15 \cdot 4)\end{array}$ & 42 & 1.77 \\
\hline$\left[\mathrm{NiL} \mathrm{Cl}_{2}\right.$ & $\mathrm{NiC}_{42} \mathrm{H}_{36} \mathrm{~N}_{10} \mathrm{O}_{6} \mathrm{Cl}_{2}$ & Brown & 54 & $\begin{array}{c}6 \cdot 3 \\
(6 \cdot 5)\end{array}$ & $\begin{array}{c}55 \cdot 4 \\
(55.7)\end{array}$ & $\begin{array}{c}3 \cdot 7 \\
(4 \cdot 0)\end{array}$ & $\begin{array}{c}15 \cdot 1 \\
(15 \cdot 5)\end{array}$ & 48 & - \\
\hline$[\mathrm{CoL}] \mathrm{Cl}_{2}$ & $\mathrm{CoC}_{42} \mathrm{H}_{36} \mathrm{~N}_{10} \mathrm{O}_{6} \mathrm{Cl}_{2}$ & Red & 58 & $\begin{array}{c}6 \cdot 2 \\
(6 \cdot 5)\end{array}$ & $\begin{array}{c}55 \cdot 2 \\
(55 \cdot 7)\end{array}$ & $\begin{array}{c}3 \cdot 8 \\
(4 \cdot 0)\end{array}$ & $\begin{array}{c}15 \cdot 0 \\
(15 \cdot 4)\end{array}$ & 53 & $3 \cdot 62$ \\
\hline$[\mathrm{MnL}] \mathrm{Cl}_{2}$ & $\mathrm{MnC}_{42} \mathrm{H}_{36} \mathrm{~N}_{10} \mathrm{O}_{6} \mathrm{Cl}_{2}$ & Pale brown & 60 & $\begin{array}{c}5.9 \\
(6 \cdot 1)\end{array}$ & $\begin{array}{c}55 \cdot 3 \\
(55 \cdot 9)\end{array}$ & $\begin{array}{c}3 \cdot 9 \\
(4 \cdot 0)\end{array}$ & $\begin{array}{c}14 \cdot 8 \\
(15 \cdot 5)\end{array}$ & 44 & $5 \cdot 31$ \\
\hline$[\mathrm{ZnL}] \mathrm{Cl}_{2}$ & $\mathrm{ZnC}_{42} \mathrm{H}_{36} \mathrm{~N}_{10} \mathrm{O}_{6} \mathrm{Cl}_{2}$ & Pale brown & 62 & $\begin{array}{c}7 \cdot 0 \\
(7 \cdot 2)\end{array}$ & $\begin{array}{c}54 \cdot 8 \\
(55 \cdot 3)\end{array}$ & $\begin{array}{c}3.7 \\
(3.9)\end{array}$ & $\begin{array}{c}14 \cdot 9 \\
(15 \cdot 3)\end{array}$ & 56 & - \\
\hline$[\mathrm{VOL}] \mathrm{SO}_{4}$ & $\mathrm{VC}_{42} \mathrm{H}_{36} \mathrm{~N}_{10} \mathrm{O}_{11} \mathrm{~S}$ & Green & 56 & $\begin{array}{c}5 \cdot 1 \\
(5 \cdot 4)\end{array}$ & $\begin{array}{c}53 \cdot 2 \\
(53 \cdot 7)\end{array}$ & $\begin{array}{c}3 \cdot 5 \\
(3 \cdot 8)\end{array}$ & $\begin{array}{c}14 \cdot 5 \\
(14 \cdot 9)\end{array}$ & 36 & 1.65 \\
\hline$[\mathrm{CdL}] \mathrm{Cl}_{2}$ & $\mathrm{CdC}_{42} \mathrm{H}_{36} \mathrm{~N}_{10} \mathrm{O}_{6} \mathrm{Cl}_{2}$ & Yellow & 59 & $\begin{array}{c}11 \cdot 3 \\
(11.7)\end{array}$ & $\begin{array}{c}52 \cdot 2 \\
(52 \cdot 6)\end{array}$ & $\begin{array}{c}3 \cdot 6 \\
(3 \cdot 8)\end{array}$ & $\begin{array}{c}14 \cdot 3 \\
(14 \cdot 6)\end{array}$ & 43 & - \\
\hline$[\mathrm{HgL}] \mathrm{Cl}_{2}$ & $\mathrm{HgC}_{42} \mathrm{H}_{36} \mathrm{~N}_{10} \mathrm{O}_{6} \mathrm{Cl}_{2}$ & Pale brown & 60 & $\begin{array}{c}18 \cdot 7 \\
(19 \cdot 1)\end{array}$ & $\begin{array}{c}47 \cdot 8 \\
(48 \cdot 1)\end{array}$ & $\begin{array}{c}3 \cdot 2 \\
(3 \cdot 4)\end{array}$ & $\begin{array}{c}12 \cdot 9 \\
(13 \cdot 4)\end{array}$ & 48 & - \\
\hline
\end{tabular}


$m / z 776$ which was also supported by the 'nitrogen rule', since the compound possesses ten nitrogen atoms. The molecular ion peak for the copper complex, observed at $\mathrm{m} / \mathrm{z} 910$ confirms the stoichiometry of metal chelates as ML type. It is also supported by the mass spectra of other complexes.

\subsection{Infrared spectra}

The IR spectra provide valuable information regarding the nature of functional group attached to the metal atom. The IR spectra of the ligand showed a broad band in the region $3200-3600 \mathrm{~cm}^{-1}$, assignable to intramolecular hydrogen bonded $-\mathrm{OH}$ groups. The appearance of this peak in all the spectra of the complexes indicates that the $-\mathrm{OH}$ group is free from complexation. The spectrum of the ligand shows two different $-\mathrm{C}=\mathrm{N}$ bands in the region $1590-1550 \mathrm{~cm}^{-1}$, which is shifted to lower frequencies in the spectra of all the complexes $\left(1570-1520 \mathrm{~cm}^{-1}\right)$ indicating the involvement of $-\mathrm{C}=\mathrm{N}$ nitrogen in coordination to the metal ion. ${ }^{26,27}$ Accordingly, the ligand acts as a tetradentate chelating agent, bonded to the metal ion via the four nitrogen $(-\mathrm{C}=\mathrm{N})$ atoms of the Schiff base (figure 2). Assignment of the proposed coordination sites is further supported by the appearance of medium bands at $450-400 \mathrm{~cm}^{-1}$ which could be attributed to $\nu_{\mathrm{M}-\mathrm{N}}$ respectively. ${ }^{28,29}$ In addition, the vanadyl complex shows a band at $940 \mathrm{~cm}^{-1}$ attributed to $\mathrm{V}=\mathrm{O}$ frequency. ${ }^{30}$

\section{$3.3{ }^{1} H$ NMR spectra}

The ${ }^{1} \mathrm{H}$ NMR spectrum of the compound I, recorded in $\mathrm{CDCl}_{3}$ showed the following signals: $=\mathrm{C}-\mathrm{CH}_{3}$

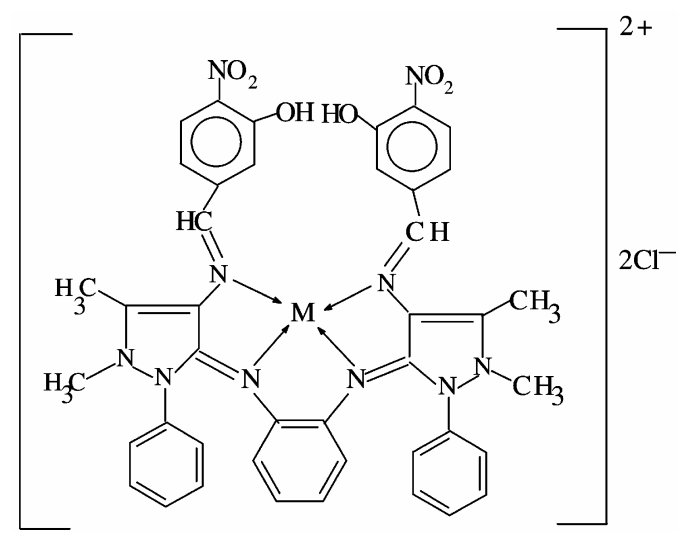

Figure 2. The proposed structures of the Schiff base complexes. $\mathrm{M}=\mathrm{Cu}(\mathrm{II}), \mathrm{Ni}(\mathrm{II}), \mathrm{Co}(\mathrm{II}), \mathrm{Mn}(\mathrm{II}), \mathrm{Zn}(\mathrm{II})$, $\mathrm{Cd}(\mathrm{II}), \mathrm{Hg}$ (II) and $\mathrm{VO}(\mathrm{IV})$. proton at $2.5 \mathrm{ppm}(s, 3 \mathrm{H}), \mathrm{N}-\mathrm{CH}_{3}$ at $3.3 \mathrm{ppm}(s$, $3 \mathrm{H})$, phenyl as multiplet at $7.2-7.8 \mathrm{ppm}(\mathrm{m}, 8 \mathrm{H})$, $-\mathrm{CH}=\mathrm{N}-$ at $9.7 \mathrm{ppm}(s, \mathrm{H})$. Furthermore, the peak obtained at $13.3 \mathrm{ppm}(s, \mathrm{H})$ is attributable to phenolic -OH group present in the 3-hydroxy-4-nitrobenzaldehyde moiety. The ${ }^{1} \mathrm{H}$ NMR spectra of the ligand (L) and its zinc complex were recorded in DMSO$d_{6}$. The ${ }^{1} \mathrm{H}$ NMR spectrum of the ligand shows the following signals: $=\mathrm{C}-\mathrm{CH}_{3}$ proton at $2.4 \mathrm{ppm}(\mathrm{s}$, $6 \mathrm{H}), \mathrm{N}-\mathrm{CH}_{3}$ at $3.2 \mathrm{ppm}(s, 6 \mathrm{H})$, phenyl as multiplet at $6.9-7.5 \mathrm{ppm}(m, 20 \mathrm{H}),-\mathrm{CH}=\mathrm{N}-$ at $9.8 \mathrm{ppm}(s$, $2 \mathrm{H})$ and the peak at $13.4 \mathrm{ppm}(s, 2 \mathrm{H})$ is attributable to the phenolic - $\mathrm{OH}$ group present in the 3 -hydroxy4-nitrobenzaldehyde moiety. The presence of phenolic $-\mathrm{OH}$ proton noted for the $\mathrm{Zn}$ complex confirms the $-\mathrm{OH}$ proton free from complexation. The azomethine proton signal in the spectrum of the $\mathrm{Zn}$ complex is shifted downfield compared to the free ligand, suggesting deshielding of the azomethine group due to coordination with metal ion. There is no appreciable change in all the other signals of this complex.

\subsection{Electronic absorption spectra}

The electronic absorption spectra of the Schiff base, $\mathrm{Cu}(\mathrm{II}), \mathrm{Ni}(\mathrm{II}), \mathrm{Co}(\mathrm{II})$ and $\mathrm{VO}(\mathrm{IV})$ complexes were recorded at $300 \mathrm{~K}$. The absorption region, band assignment and the proposed geometry of the complexes are given in table 2 . Based on these data, a squareplanar geometry has been assigned to the complexes except VO(IV) complex which has square-pyramidal geometry (figure 2). These values are comparable with other reported complexes. ${ }^{31-34}$

\subsection{Redox studies}

The cyclic voltammogram of the $\mathrm{Cu}$ complex in DMSO scan rate $100 \mathrm{mVs}^{-1}$ shows a well-defined redox process corresponding to the formation of $\mathrm{Cu}(\mathrm{II}) /$ $\mathrm{Cu}(\mathrm{I})$ couple at $E p_{a}=0.53 \mathrm{~V}$ and $E p_{c}=0.24 \mathrm{~V}$. This couple is found to be quasi-reversible with $\Delta E_{p}=0.29 \mathrm{~V}$ and the ratio of anodic to cathodic peak currents corresponding to a simple one-electron process.

The cyclic voltammogram for the vanadyl complex was recorded in DMSO solution. Table 3 shows two well-defined one-electron transfer redox peaks, corresponding to the formation of the $\mathrm{VO}(\mathrm{IV}) / \mathrm{VO}(\mathrm{V})$ and VO(IV)/VO(III) couples. ${ }^{35,36}$ The peak current functions of both waves in complex are different which indicate the involvement of two different 
Table 2. Electronic absorption spectral data of the compounds.

\begin{tabular}{lcccc}
\hline Compound & Solvent & Absorption $\left(\mathrm{cm}^{-1}\right)$ & Band assignment & Geometry \\
\hline $\mathrm{L}$ & EtOH & 40816 & INCT & - \\
& & 25445 & INCT & \\
{$[\mathrm{CuL}] \mathrm{Cl}_{2}$} & $\mathrm{DMF}$ & 41493 & INCT & Square \\
& & 26455 & INCT & Planar \\
& & 20533 & ${ }^{2} \mathrm{~B}_{1} \mathrm{~g} \rightarrow{ }^{2} \mathrm{~A}_{1} \mathrm{~g}$ & \\
{$[\mathrm{NiL}] \mathrm{Cl}_{2}$} & $\mathrm{DMF}$ & 42016 & $\mathrm{INCT}$ & Square \\
& & 26954 & $\mathrm{INCT}$ & Planar \\
& & 19531 & ${ }^{1} \mathrm{~A}_{1} \mathrm{~g} \rightarrow{ }^{1} \mathrm{~A}_{2} \mathrm{~g}$ & \\
& & 15797 & ${ }^{1} \mathrm{~A}_{1} \mathrm{~g} \rightarrow{ }^{1} \mathrm{~B}_{1} \mathrm{~g}$ & \\
{$[\mathrm{CoL}] \mathrm{Cl}_{2}$} & $\mathrm{DMF}$ & 41493 & $\mathrm{INCT}$ & Square \\
& & 26455 & $\mathrm{INCT}$ & Planar \\
& & 19607 & ${ }^{1} \mathrm{~A}_{1} \mathrm{~g} \rightarrow{ }^{1} \mathrm{~B}_{1} \mathrm{~g}$ & \\
{$[\mathrm{VOL}] \mathrm{SO}_{4}$} & $\mathrm{DMF}$ & 41841 & $\mathrm{INCT}$ & Square \\
& & 26109 & $\mathrm{INCT}$ & Pyramidal \\
& & 19920 & ${ }^{2} \mathrm{~B}_{2} \rightarrow{ }^{2} \mathrm{~A}_{1}$ & \\
& & 12315 & ${ }^{2} \mathrm{~B}_{2} \rightarrow{ }^{2} \mathrm{E}$ & \\
\hline
\end{tabular}

Table 3. Cyclic voltammetric data of copper and vanadium complexes in DMSO containing $0 \cdot 1 \mathrm{M}$ (TBAP). Scan rate $100 \mathrm{mVs}^{-1}$.

\begin{tabular}{llcccc}
\hline Complex & Couple & $E p_{c}(\mathrm{~V})$ & $E p_{a}(\mathrm{~V})$ & $I p_{c}(\mu \mathrm{A})$ & $I p_{a}(\mu \mathrm{A})$ \\
\hline [CuL]Cl $_{2}$ & $\mathrm{Cu}(\mathrm{II}) / \mathrm{Cu}(\mathrm{I})$ & 0.24 & 0.53 & 11.05 & -10.26 \\
[VOL]SO $_{4}$ & $\mathrm{VO}(\mathrm{IV}) / \mathrm{VO}(\mathrm{V})$ & 0.53 & 0.62 & 15.28 & -15.55 \\
& $\mathrm{VO}(\mathrm{IV}) / \mathrm{VO}(\mathrm{III})$ & -1.03 & -0.57 & 6.75 & -7.44 \\
\hline
\end{tabular}

Table 4. ESR spectral data of copper and vanadium complexes in DMSO at 300 and $77 \mathrm{~K}$.

\begin{tabular}{lccrccc}
\hline Complex & $A_{\|}$ & $A_{\perp}$ & $A_{\text {iso }}$ & $g_{\|}$ & $g_{\perp}$ & $g_{\text {iso }}$ \\
\hline [CuL]Cl $_{2}$ & 165 & 55 & 78 & 2.38 & 2.06 & 2.12 \\
[VOL] $\mathrm{SO}_{4}$ & 172 & 71 & 104 & 1.97 & 2.03 & 1.98 \\
\hline
\end{tabular}

electroactive species in solution ${ }^{37,38}$ corresponding to $\mathrm{VO}(\mathrm{V})$ and $\mathrm{VO}(\mathrm{III})$.

\section{$3.6 \quad E S R$}

The ESR spectrum of copper complex was recorded in DMSO at 300 and $77 \mathrm{~K}$. The frozen solution spectrum shows a well-resolved four-line spectrum and no features characteristic for a dinuclear complex. This is also supported by the magnetic moment of $\mathrm{Cu}$ complex (1.77 BM) which confirms the mononuclear nature of the complex. The spin Hamiltonian parameters, calculated for the copper complex from the spectra, are given in table 4 . The $g$ tensor values of this copper(II) complex can be used to derive the ground state. In square-planar complexes, the unpaired electron lies in the $d_{x^{2}-y^{2}}$ orbital giving $g_{\|}>g_{\perp}>2$ while the unpaired electron lies in the $d_{z^{2}}$ orbital giving $g_{\perp}>g_{\|}>2$. From the observed values, it is clear that $g_{\|}>\mathrm{g}_{\perp}>2$ suggesting that the complex is square-planar. This is also supported by the fact that the unpaired electron lies predominantly in the $d_{x^{2}-y^{2}}$ orbital, ${ }^{39-42}$ as evident from the value of the exchange interaction term $G$, estimated from the expression:

$$
G=\left(g_{\|}-2 \cdot 0023\right) /\left(g_{\perp}-2 \cdot 0023\right) .
$$

If $G>4 \cdot 0$, the local tetragonal axes are aligned parallel or only slightly misaligned. If $G<4 \cdot 0$, significant exchange coupling is present and the misalignment is appreciable. The observed value for the exchange interaction parameter for the $\mathrm{Cu}$ complex $(G=6.5)$ suggests that the local tetragonal axes are aligned parallel or slightly misaligned, and the unpaired electron is present in the $d_{x^{2}-y^{2}}$ orbital. This result also indicates that the exchange coupling effects are not operative in the present complex. ${ }^{43}$ 
The ESR spectra of the vanadyl complex, recorded in DMSO solution at 300 and $77 \mathrm{~K}$, show a typical eight-line and sixteen-line pattern respectively. The isotropic ESR parameters $g_{\text {iso }}=1.98$ and $A_{\text {iso }}=104$ can be calculated from the position spacing of the resonance lines from room temperature solution spectrum of the complex. The spectrum is like a typical eight-line pattern which shows that a single vanadium is present in the molecule which is a monomer. In the frozen solid state, the spectrum shows two types of resonance components, one set due to parallel features and the other due to perpendicular features, which indicate axially symmetric anisotropy with well-resolved sixteen-line hyperfine splitting, characteristic of an interaction between the electron and vanadium nuclear spin. From the anisotropic spectrum, the anisotropic parameters were calculated. The observed order $\left(A_{\|}=172>A_{\perp}=71\right.$; $\left.g_{\perp}=2.03>g_{\|}=1.97\right)$ indicates that the unpaired electron is present in the $d_{x y}$ orbital with squarepyramidal geometry around the VO(IV) chelates. ${ }^{44-48}$

\subsection{Antimicrobial activity}

For in vitro antimicrobial activity, the investigated compounds were tested against the bacteria $S$. typhi, $S$. aureus, E. coli, and B. subtilis and fungi $A$. niger, $A$. flavus and $R$. bataicola. The minimum inhibitory concentration (MIC) values of the investigated compounds are summarized in tables 5 and 6 . The values indicate that most complexes have higher antimicrobial activity than the free ligand. Such increased activity of the metal chelates can be explained on the basis of chelation theory. On chelation, the polarity of the metal ion will be reduced to a greater extent due to the overlap of the ligand

Table 5. Antibacterial activity of the Schiff base ligand and its metal complexes (minimum inhibitory concentration $\times 10^{-2} \mathrm{M}$ ).

\begin{tabular}{lcccc}
\hline Compound & S. typhi & S. aureus & E. coli & B. subtilis \\
\hline $\mathrm{L}$ & $5 \cdot 1$ & $5 \cdot 3$ & $5 \cdot 2$ & $5 \cdot 5$ \\
{$[\mathrm{CuL}] C C_{2}$} & $4 \cdot 0$ & $3 \cdot 8$ & $4 \cdot 1$ & $3 \cdot 9$ \\
{$\left[\mathrm{NiL}_{2}\right.$} & $4 \cdot 2$ & $4 \cdot 1$ & $4 \cdot 0$ & $4 \cdot 2$ \\
{$[\mathrm{CoL}] C C_{2}$} & $4 \cdot 0$ & $4 \cdot 5$ & $4 \cdot 1$ & $4 \cdot 4$ \\
{$\left[\mathrm{MnL}_{2}\right.$} & $4 \cdot 1$ & $4 \cdot 4$ & $4 \cdot 3$ & $4 \cdot 6$ \\
{$[\mathrm{ZnL}] C l_{2}$} & $4 \cdot 4$ & $4 \cdot 5$ & $4 \cdot 3$ & $4 \cdot 1$ \\
{$[\mathrm{VOL}] \mathrm{CO}_{4}$} & $3 \cdot 9$ & $4 \cdot 0$ & $4 \cdot 1$ & $4 \cdot 2$ \\
{$[\mathrm{CdL}] C C_{2}$} & $4 \cdot 1$ & $4 \cdot 3$ & $4 \cdot 0$ & $4 \cdot 2$ \\
{$[\mathrm{HgL}] C C_{2}$} & $4 \cdot 5$ & $4 \cdot 4$ & $4 \cdot 6$ & $4 \cdot 3$ \\
\hline
\end{tabular}

orbital and partial sharing of the positive charge of the metal ion with donor groups. Further, it increases the delocalization of $\pi$-electrons over the whole chelate ring and enhances the penetration of the complexes into lipid membranes and blocking of the metal binding sites in the enzymes of microorganisms. These complexes also disturb the respiration process of the cell and thus block the synthesis of proteins, which restricts further growth of the organism. ${ }^{21}$

\subsection{DNA cleavage studies}

The cleavage efficiency of the complexes compared to that of the control is due to their efficient DNAbinding ability. The metal complexes were able to convert supercoiled DNA into open circular DNA. The proposed general oxidative mechanisms and account of DNA cleavage by hydroxyl radicals via abstraction of a hydrogen atom from sugar units that predict the release of specific residues arising from transformed sugars, depending on the position from which the hydrogen atom is removed. ${ }^{49}$ The cleavage is inhibited by free radical scavengers implying that hydroxyl radical or peroxy derivatives mediate the cleavage reaction. The reaction is modulated by a metallocomplexes bound hydroxyl radical or a peroxo species generated from the co-reactant $\mathrm{H}_{2} \mathrm{O}_{2}$.

In the present study, the CT-DNA gel electrophoresis experiment was conducted at $35^{\circ} \mathrm{C}$ using our synthesized complexes in the presence of $\mathrm{H}_{2} \mathrm{O}_{2}$ as an oxidant. As can be seen from the results (figure 3), at very low concentration, few complexes exhibit nuclease activity in the presence of $\mathrm{H}_{2} \mathrm{O}_{2}$. Control experiment using DNA alone (lane 1) does not show any significant cleavage of CT-DNA even on longer

Table 6. Antifungal activity of the Schiff base ligand and its metal complexes (minimum inhibitory concentration $\times 10^{-2} \mathrm{M}$ ).

\begin{tabular}{lccc}
\hline Compound & A. niger & A. flavus & R. bataicola \\
\hline $\mathrm{L}$ & $6 \cdot 5$ & $6 \cdot 3$ & $6 \cdot 4$ \\
{$[\mathrm{CuL}] \mathrm{Cl}_{2}$} & $4 \cdot 6$ & $5 \cdot 0$ & $4 \cdot 8$ \\
{$\left[\mathrm{NiL}_{2}\right.$} & $4 \cdot 8$ & $5 \cdot 2$ & $5 \cdot 3$ \\
{$[\mathrm{CoL}] C C_{2}$} & $5 \cdot 1$ & $4 \cdot 9$ & $4 \cdot 8$ \\
{$\left[\mathrm{MnL}_{2}\right.$} & $4 \cdot 8$ & $5 \cdot 2$ & $5 \cdot 0$ \\
{$[\mathrm{ZnL}] \mathrm{Cl}_{2}$} & $5 \cdot 2$ & $4 \cdot 8$ & $5 \cdot 1$ \\
{$\left[\mathrm{VOL}_{2}\right.$} & $4 \cdot 8$ & $4 \cdot 9$ & $5 \cdot 0$ \\
{$[\mathrm{CdL}] C C_{2}$} & $5 \cdot 3$ & $5 \cdot 1$ & $5 \cdot 2$ \\
{$[\mathrm{HgL}]{ }_{2}$} & $5 \cdot 1$ & $5 \cdot 3$ & $5 \cdot 4$ \\
\hline
\end{tabular}




$\begin{array}{lllllllll}\text { Lane } 1 & 2 & 3 & 4 & 5 & 6 & 7 & 8 & 9\end{array}$

Figure 3. Changes in the agarose gel electrophoretic pattern of calf-thymus DNA induced by $\mathrm{H}_{2} \mathrm{O}_{2}$ and metal complexes: DNA alone (lane 1); DNA $+[\mathrm{CuL}] \mathrm{Cl}_{2}+$ $\mathrm{H}_{2} \mathrm{O}_{2}$ (lane 2); DNA + [NiL]Cl $2+\mathrm{H}_{2} \mathrm{O}_{2}$ (lane 3); DNA + $[\mathrm{CoL}] \mathrm{Cl}_{2}+\mathrm{H}_{2} \mathrm{O}_{2}$ (lane 4); DNA $+\left[\mathrm{MnL}^{2} \mathrm{Cl}_{2}+\mathrm{H}_{2} \mathrm{O}_{2}\right.$ (lane 5); $\mathrm{DNA}+[\mathrm{ZnL}] \mathrm{Cl}_{2}+\mathrm{H}_{2} \mathrm{O}_{2}$ (lane 6); $\mathrm{DNA}+[\mathrm{VOL}]$ $\mathrm{SO}_{4}+\mathrm{H}_{2} \mathrm{O}_{2}$ (lane 7); DNA + [CdL]Cl $2+\mathrm{H}_{2} \mathrm{O}_{2}$ (lane 8); $\mathrm{DNA}+\left[\mathrm{HgL}_{\mathrm{C}} \mathrm{Cl}_{2}+\mathrm{H}_{2} \mathrm{O}_{2}\right.$ (lane 9).

exposure time. From the observed results, we conclude that the complexes, copper complex (lane 2), nickel complex (lane 3) and cobalt complex (lane 4) cleave DNA as compared to control DNA while other complexes (lane 5-9) do not cleave DNA in the presence of $\mathrm{H}_{2} \mathrm{O}_{2}$. Probably this may be due to the formation of redox couple of the metal ions and its behaviour. Further, the presence of a smear in the gel diagram indicates the presence of radical cleavage. $^{50}$

\section{Conclusions}

In this report, coordination chemistry of a Schiff base ligand, obtained from the reaction of 4-aminoantipyrine, 3-hydroxy-4-nitrobenzaldehyde and $o$ phenylenediamine, is described. $\mathrm{Cu}(\mathrm{II}), \mathrm{Ni}(\mathrm{II})$, $\mathrm{Co}(\mathrm{II}), \mathrm{Mn}(\mathrm{II}), \mathrm{Zn}(\mathrm{II}), \mathrm{VO}(\mathrm{IV}), \mathrm{Hg}(\mathrm{II})$ and $\mathrm{Cd}(\mathrm{II})$ complexes have been synthesized using the Schiff base ligand and characterized by spectral and analytical data. Based on these data, a square-planar geometry has been assigned to the complexes except VO(IV) complex which has square-pyramidal geometry. The metal complexes have higher antimicrobial activity than the ligand. The interaction of these complexes with CT-DNA was investigated by gel electrophoresis. From the observation, $\mathrm{Cu}, \mathrm{Ni}$ and Co complexes cleave DNA as compared to control DNA and other complexes in the presence of $\mathrm{H}_{2} \mathrm{O}_{2}$.

\section{Acknowledgements}

JD thanks the Tamil Nadu Government for financial assistance. NR and AS express their sincere thanks to the University Grants Commission, New Delhi for financial assistance.

\section{References}

1. Hitoshi T, Tamao N, Hideyuki A, Manabu F and Takayuki M 1997 Polyhedron 163787

2. Punniyamurthy T, Kalra S J S and Iqbal J 1995 Tetrahedron Lett. 368497

3. Trivedi G S and Desai N C 1992 Indian J. Chem. B31 366

4. Choi Y K, Chjo K H, Park S M and Doddapaneni N 1995 J. Electrochem. Soc. 1424107

5. Katia B, Simon L, Anne R, Gerard C, Francoise D and Bernard M 1996 Inorg. Chem. 35387

6. Hodnett E M and Mooney P D $1970 \mathrm{~J}$. Med. Chem. 13786

7. Hodnett E M and Dunn W J 1972 J. Med. Chem. 15 339

8. Sigman D S, Graham D R and Aaurora V D $1979 \mathrm{~J}$. Biol. Chem. 2541269

9. Downey V M, Que B R and So A G 1980 Biochem. Biophys. Res. Commun. 93264

10. Marshall E L, Graham D R and Reith K A 1981 Biochemistry 20224

11. Ueda J I, Takai M and Shimazu Y 1998 Arch. Biochem. Biophys. 357231

12. Radhakrishnan P K 1986 Polyhedron 5995

13. Maurya R C, Mishra D D, Pandey M, Shukla P and Rathour R 1992 Synth. React. Inorg. Met.-Org. Chem. 23167

14. Agarwal R K, Garg P, Agarwal H and Chandra D 1997 Synth. React. Inorg. Met.-Org. Chem. 27251

15. Singh L, Tyagi N, Dhaka N P and Sindhu S K 1999 Asian J. Chem. 11503

16. Jha N K and Joshi D M 1986 Synth. React. Inorg. Met.-Org. Chem. 16947

17. Thomas P and Parmeshwaran G 1992 J. Indian Chem. Soc. 69117

18. Mishra A P, Srinivastava V and Srinivastava S K 1995 Synth. React. Inorg. Met.-Org. Chem. 2521

19. Shankar R, Kumar R P and Ramalingam S K 1986 Polyhedron 5991

20. Kriza A, Reiss A, Florea S and Caproiu 2000 J. Indian Chem. Soc. 77207

21. Dharmaraj N, Viswanathamurthi P and Natarajan K 2001 Trans. Met. Chem. 26105

22. Raman N, Kulandaisamy A and Jeyasubramanian K 2002 Polish J. Chem. 761085

23. Marmur J 1961 J. Mol. Biol. 3208

24. Irobi O N, Moo-Young M and Anderson W A 1996 Int. J. Pharm. 3487

25. Pelczar M J, Chan E C S and Krieg N R 1998 Microbiology (New York: Blackwell Science) 5th edn 
26. Iskander M F, Ei-Syed L and Ismail K Z 1979 Trans. Met. Chem. 4225

27. Thankamony M and Mohanan K 2007 Indian J. Chem. A46 249

28. Thomas M, Nair M K M and Radhakrishan R K 1995 Synth. React. Inorg. Met.-Org. Chem. 25471

29. Nakamoto K 1997 Infrared and Raman spectra of inorganic and coordination compounds (New York: Wiley) 3rd edn

30. Xiu R B, Mintz F L, You X Z, Wang R X, Yue Q, Meng Q J, Lu Y J and Derveer D V 1996 Polyhedron 154585

31. Lever A B P 1968 Inorganic electronic spectroscopy (New York: Elsevier) 2nd edn

32. Sharada L N and Ganorkar M C 1988 Indian J. Chem. A27 617

33. Warad D U, Satish C D, Kulkarini V H and Bajgur C S 2000 Indian J. Chem. A39 415

34. Farmer R L and Urbach F L 1974 Inorg. Chem. 13587

35. Dutton K G, Fallon G D and Murray K S 1988 Inorg. Chem. 2734

36. Knopp P, Weighardt K, Nuber B, Weiss J and Sheldrick W S 1990 Inorg. Chem. 29363

37. Nawi M A and Riechel T L 1981 Inorg. Chem. 20 1974

38. Matsubayashi G, Akiba K and Tanaka T 1988 Inorg. Chem. 274744
39. Kadam R M, Sastry M D, Bhide M K, Chavan S A, Yakhmi J V and Khan O 1997 Chem. Phys. Lett. 281 292

40. Base M, Ohta K, Babu Y and Sastry M D 2000 Chem. Phys. Lett. 324330

41. Ray R K and Kaufiman G B 1990 Inorg. Chim. Acta 173207

42. Jeyasubramanian $\mathrm{K}$, Samath $\mathrm{S}$ A, Thambidurai S, Murugesan R and Ramalingam S K 1996 Trans. Met. Chem. 2076

43. Benial A M F, Ramakrishnan V and Murugesan R 2000 Spectrochim. Acta $\mathbf{A 5 6} 2775$

44. Boucher L J, Tyanan E C and Yen T F 1969 Electron spin resonance of metal chelates (New York: Plenum Press)

45. Boucher L J and Yen T F 1969 Inorg. Chem. 8689

46. Kadish K M, Sazou D, Araullo C, Liu Y M, Saoiabi A, Ferhat M and Guilard R 1988 Inorg. Chem. 27 2313

47. Dodwad S S, Dhamnaskr R S and Prabhu P S 1989 Polyhedron 81748

48. Kivelson D and Lee S K 1964 J. Chem. Phys. 41 1896

49. Prativel G, Pitie M, Bernadou J and Meunier B 1991 Angew. Chem. Int. Ed. Eng. 30702

50. Thomas A M, Naik A D, Nethaji M and Chakravarty A R 2004 Indian J. Chem. A43 691 